\title{
Simulation of strong motions in Fukuoka City during the 2005 West Off Fukuoka Prefecture Earthquake with special reference to thick Quaternary sediments around the Kego fault
}

\author{
Toshimi Satoh ${ }^{1}$ and Hiroshi Kawase ${ }^{2}$ \\ ${ }^{1}$ Institute of Technology, Shimizu Corporation, 4-17 Etchujima 3-chome, Koto-ku, Tokyo 135-8530, Japan \\ ${ }^{2}$ Deptartment of Architecture and Urban Design, Faculty of Human-Environment Studies, \\ Kyushu University, 6-10-1 Hakozaki, Higashi-ku, Fukuoka 812-8581, Japan \\ (Received August 8, 2005; Revised December 6, 2005; Accepted December 7, 2005; Online published January 27, 2006)
}

\begin{abstract}
We simulate velocity records at two stations in the building damaged area near the Kego fault in Fukuoka City by 1-D wave propagation theory during the 2005 West Off Fukuoka Prefecture Earthquake, Japan. Here we use the pre-Tertiary bedrock wave deconvolved from the record observed at a K-NET station outside of the damaged area. The observed velocity waveforms and pseudo velocity response spectra in the period range from 0.7 to 10 seconds in the predominant direction $\left(\mathrm{N} 20^{\circ} \mathrm{E}\right)$ components are reasonably reproduced. Velocity pulses with a period of about 1 to 2 seconds in observed velocity waveforms at two stations are found to be amplified by the Quaternary sediments above the pre-Tertiary bedrock. After we confirmed the validity of our approach through the simulation, we predict the peak ground velocity (PGV) distribution around the Kego fault by considering 1-D response of Quaternary sediments at each site. The predicted PGV distribution of $\mathrm{N} 20^{\circ} \mathrm{E}$ components is largest (about $80 \mathrm{~cm} / \mathrm{s}$ ) in the northeast side of the Kego fault and agrees well with the building damage distribution. Our result shows that the 1-D site responses of Quaternary sediments mainly contributed to the difference of PGVs inside and outside of the damaged area in Fukuoka City.
\end{abstract}

Key words: 2005 West Off Fukuoka Prefecture Earthquake, one-dimensional site response, peak ground velocity, Quaternary sediment, Kego fault.

\section{Introduction}

The 2005 West Off Fukuoka Prefecture Earthquake with JMA (Japan Meteorological Agency) magnitude $M_{J}$ of 7.0 and the focal depth of $9.2 \mathrm{~km}$ (JMA, 2005) occurred on 20 March 2005 in the north coast of the Kyushu island, southwestern part of Japan. The seismic intensity on JMA scale was reported to be 6-minus in Fukuoka City, which is located about $28 \mathrm{~km}$ away from the hypocenter. The damaged buildings were distributed in the limited area in the northeastern side of an active fault, the Kego fault, in Fukuoka City (e.g., Kawano and Inoue, 2005; Kosa et al., 2005; Kawase et al., 2005). Peak ground velocities (PGVs) of horizontal components observed at two strong motion stations (FKOS01 and CTI) in the damaged area were larger than the PGVs observed at a strong motion station (FKO006) outside of the damaged area, although FKO006 was located only $2 \mathrm{~km}$ away from FKOS01 and CTI to the east. It has been known that Quaternary sediments are deepest (about $50 \mathrm{~m}$ or greater) in the northeastern side of the Kego fault and getting shallower to the east (e.g. Editing Group of Fukuoka soil map, 1981). Therefore it is possible that the site-responses of Quaternary sediments contributed to the difference of strong ground motions inside and outside of the damaged area.

Copyright (c) The Society of Geomagnetism and Earth, Planetary and Space Sciences (SGEPSS); The Seismological Society of Japan; The Volcanological Society of Japan; The Geodetic Society of Japan; The Japanese Society for Planetary Sciences; TERRAPUB
In this study we evaluate the effects of one-dimensional (1-D) site responses of Quaternary sediments on strong motions around the Kego fault in order to delineate the cause of the clear spatial difference of structural damage. Since PS logging was performed at FKO006 by National Research Institute for Earth Science and Disaster Prevention (NIED, 2005a), we first deconvolve the 1-D theoretical $S$-wave amplification from the record at FKO006 to get the preTertiary bedrock wave. Then we simulate velocity records at FKOS01 and CTI using the pre-Tertiary bedrock wave and the 1-D model based on thickness information of Quaternary sediments above the pre-Tertiary bedrock (Editing group of Fukuoka soil map, 1981; Itoh and Kawase, 2001). We also predict the PGV distribution around the Kego fault by considering 1-D site responses of Quaternary sediments at every site (assigned in all the small districts) and compare it with the damaged building distributions.

\section{Data}

Figure 1(a) shows the locations of epicenters of the main shock, eight aftershocks (JMA, 2005), and three strong motion stations. The main shock is the strike-slip crustal earthquake with $M_{w}=6.6$ (Asano and Iwata, 2006) and the strike direction is estimated to be $\mathrm{N} 122^{\circ} \mathrm{E}$ by $\mathrm{F}$-net (NIED, 2005b). Figure 1(b) shows the contour of the Quaternary-sediment thickness (Itoh and Kawase, 2001) around the Kego fault defined by Nakata and Imaizumi (2002) and the locations of three strong motion stations 


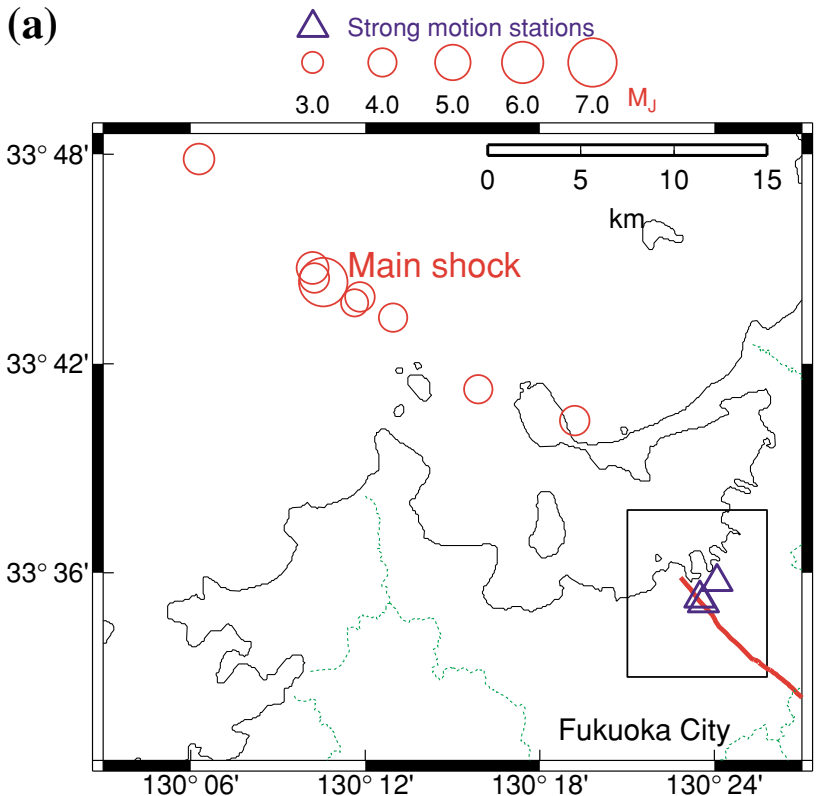

(b)

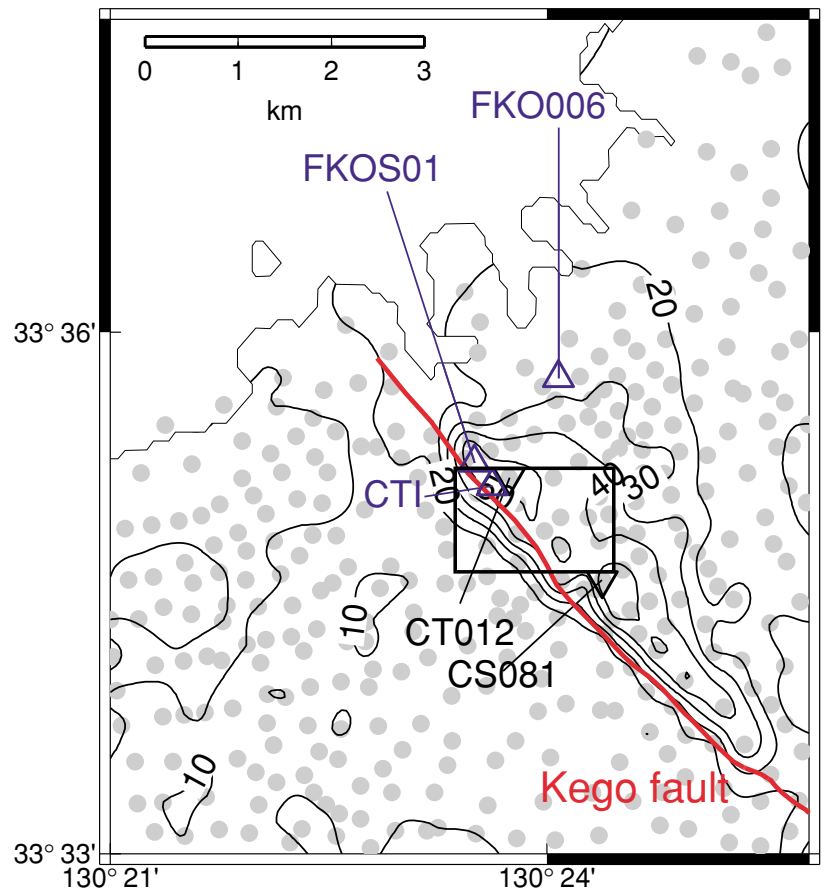

Fig. 1. (a) Locations of epicenters (JMA, 2005) of the main shock and aftershocks, and strong motion stations. A square denotes the area shown in Fig. 1(b). (b) The contour map of Quaternary-sediment thickness around the Kego fault taken from Nakata and Imaizumi (2005) within the square region shown in (b). The contour is drawn from data at each block digitized by Itoh and Kawase (2001) from Editing group of Fukuoka soil map (1981). The circles denote the data point at each block where we will predict PGV for the main shock in this study. Invert triangles denote two points where the Quaternary-sediment thickness is the largest $(54 \mathrm{~m})$. A square denotes the area shown in Fig. 2.

(FKO006, FKOS01, and CTI) in the target area. FKO006 in Tenjin 5-chome was one of the K-NET strong motion stations deployed by NIED. FKOS01 in Maizuru 3 -chome was one of seismic intensity stations deployed by Fukuoka Prefecture. Records at CTI in Daimyo 2chome were observed at the basement of a base-isolated
Table 1. Hypocentral information (JMA, 2005).

\begin{tabular}{crcc}
\hline $\begin{array}{c}\text { Origin time } \\
\text { by JST }\end{array}$ & $\begin{array}{c}\text { Depth } \\
(\mathrm{km})\end{array}$ & $M_{J}$ & $\begin{array}{c}\Delta^{*} \\
(\mathrm{~km})\end{array}$ \\
\hline 2005/03/20 10:53:40.4 & 9.2 & 7.0 & 26.3 \\
2005/03/20 11:40:04.7 & 11.9 & 4.0 & 16.4 \\
2005/03/20 11:50:04.3 & 17.8 & 4.2 & 24.4 \\
2005/03/20 20:08:22.5 & 13.4 & 4.4 & 35.6 \\
2005/03/20 20:38:16.4 & 11.2 & 4.5 & 27.3 \\
2005/03/21 06:17:00.5 & 12.2 & 3.9 & 24.4 \\
2005/03/24 23:38:42.9 & 11.1 & 4.3 & 26.9 \\
2005/03/25 03:43:18.9 & 10.9 & 4.0 & 22.3 \\
2005/04/01 21:52:13.6 & 11.9 & 4.3 & 11.6 \\
\hline
\end{tabular}

${ }^{*}$ Epicentral distance to FKO006.

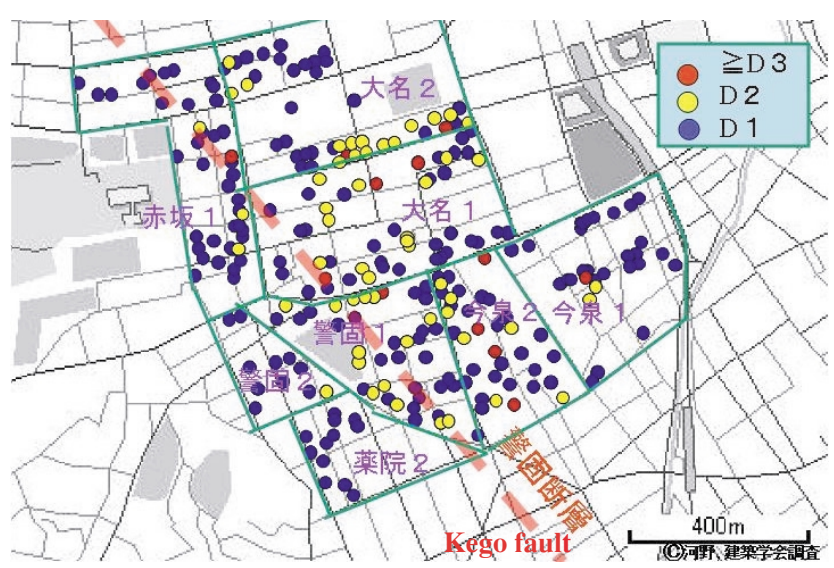

Fig. 2. Damage distribution of non-wooden buildings around the most damaged area in Fukuoka city (Kono and Inoue, 2005). Green lines denote the investigated area. D1, D2, and D3 mean slightly, partially, and half collapsed buildings, respectively. D2 and D3 are mostly distributed in the northeastern side of the Kego fault shown by a red dashed line.

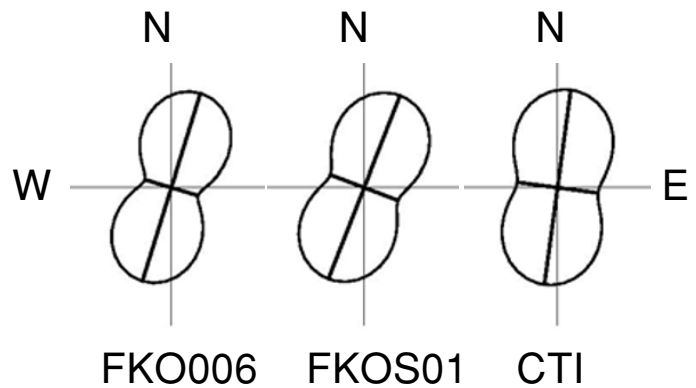

Fig. 3. Principal axis analyses results using velocity waves of NS and EW components for the main shock. Velocity ground motions of $\mathrm{N} 20^{\circ} \mathrm{E}$ direction are dominated at three stations. This predominant direction is more or less consistent with fault normal direction of the main shock.

building of the Kyushu office, CTI Engineering Co., Ltd (http://www.ctie.co.jp/earthquake/eq_20050320.html).

Three components of acceleration waves with the sampling rate of 0.01 second were recorded at these stations. The contour of the Quaternary-sediment thickness is drawn from the data at each sub-district (that is, n-chome of a district) digitized by Itoh and Kawase (2001) based on the Fukuoka soil map (Editing group of Fukuoka soil map, 


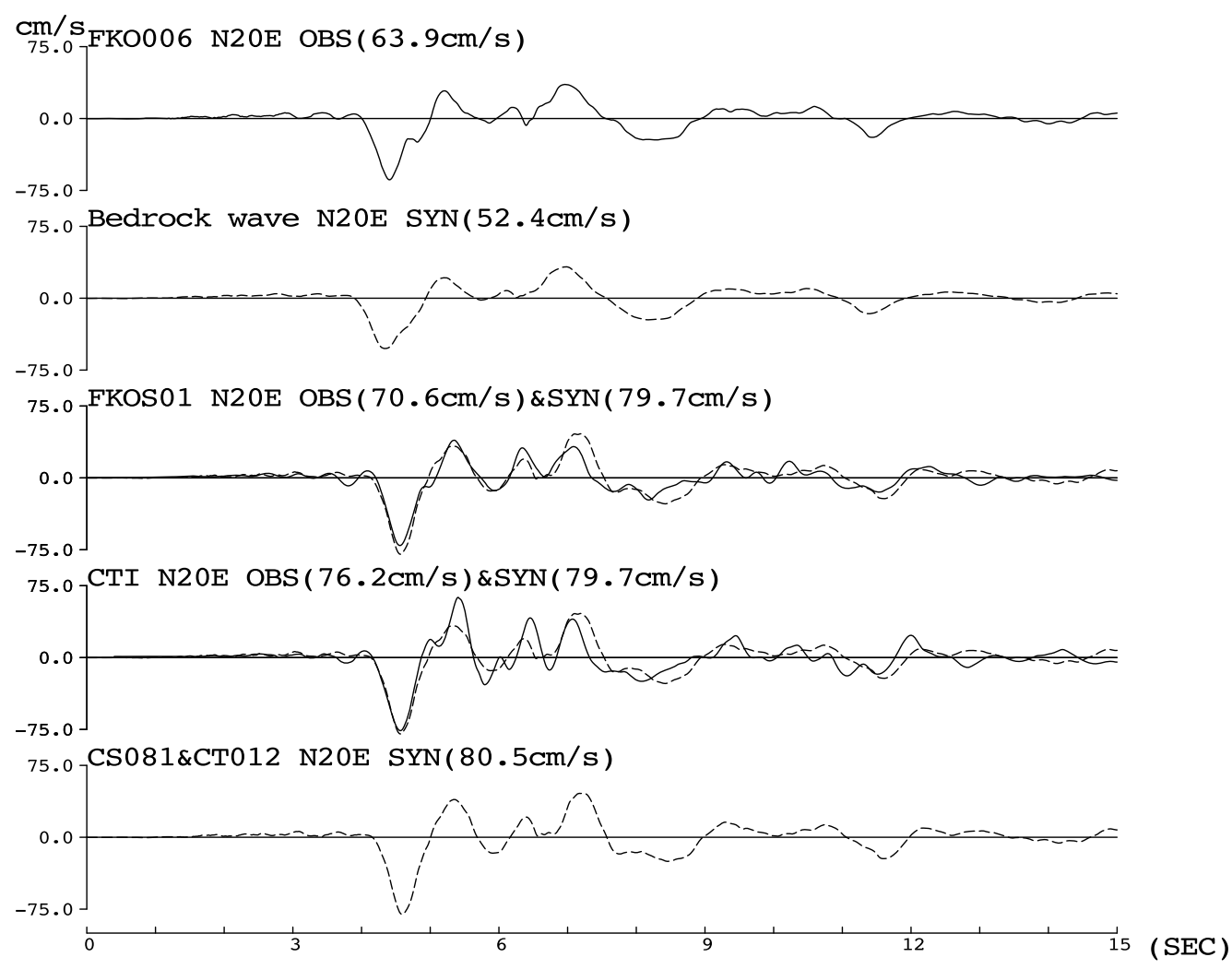

Fig. 4. Observed (solid lines) and calculated (dashed lines) velocity waveforms of $\mathrm{N} 20^{\circ} \mathrm{E}$ components for the main shock. The first, third, and fourth traces denoted by solid lines are the observed waveforms at FKO006, FKOS01, and CTI, respectively. The second trace is the pre-Tertiary bedrock wave. The third and fourth traces denoted by dashed lines are the calculated waveforms at FKOS01 and CTI, respectively. The fifth trace is the calculated waveform at CS081 and CT012.

1981). The circles in Fig. 1(b) denote the data point at the center of each sub-district where we will predict PGVs for the main shock in this study. The thickness is about $50 \mathrm{~m}$ at the northeast side along the Kego fault. It is thickest $(54 \mathrm{~m})$ at the sub-districts named CT012 and CS081, both of which are located inside the damaged area (Kawano and Inoue, 2005; Kosa et al., 2005; Kawase et al., 2005). The thickness at FKOS01 and CTI inside of the damaged area is 50 $\mathrm{m}$. The thickness at FKO006 outside of the damaged area is $25 \mathrm{~m}$. Hypocenter information (JMA, 2005) of the main shock and eight aftershocks until April 1 whose strong motion records were observed at both FKO006 and FKOS01 are listed in Table 1. At CTI only main shock records are available so far. Figure 2 shows damage distribution of nonwooden buildings around the most severally damaged area in Fukuoka city (Kawano and Inoue, 2005). Green lines denote the investigated area. D1, D2, and D3 mean slightly, partially, and half collapsed buildings, respectively. D2 and D3 are mostly distributed in the northeastern side of the Kego fault. Wooden buildings are also damaged in the same area (e.g., Kawase et al., 2005).

In this study we use $S$-wave windows with the window width of $15 \mathrm{sec}$ for both the main shock and aftershock records. The acceleration records of $S$-wave windows are integrated once in the frequency domain to get velocity records. Figure 3 shows the predominant direction on the horizontal plane calculated from the velocity waves of NS and EW components. The predominant direction at three stations is about $\mathrm{N} 20^{\circ} \mathrm{E}$ which is more or less consistent with fault normal direction of the main shock. The velocity waveforms of $\mathrm{N} 20^{\circ} \mathrm{E}$ components are shown in Fig. 4. The first, third, and fourth traces drawn by solid lines are the observed waveforms at FKO006, FKOS01, and CTI, respectively. The dashed lines are calculated waveforms mentioned later. Velocity pulses with a period of about 1 to 2 seconds are dominated. These velocity pulses mainly control the PGVs. The radiation pattern and the forward directivity effects of the asperity should create these velocity pulses because a very prominent asperity is located at the southeast side from the hypocenter (e.g., Asano and Iwata, 2006; Suzuki and Iwata, 2006). It has been pointed out that the velocity pulses with a period of 1 to 2 seconds are most influential for the structural damage to ordinary buildings (Kawase and Nagato, 2000). Therefore we use the $\mathrm{N} 20^{\circ} \mathrm{E}$ components in the following analyses to delineate the difference of strong ground motions inside and outside of the damaged area. As for the other horizontal component, we will try to reproduce it in future by considering complex amplification effects on higher frequency component.

\section{1-D Structure Model of Quaternary Sediment}

The 1-D structure model of Quaternary sediments at FKO006 is shown in Table 2. The model down to a depth of $20 \mathrm{~m}$ is made based on PS and density logging results at FKO006 provided by NIED (2005a). The pre-Tertiary bedrock depth is estimated to be $25 \mathrm{~m}$ there (Fig. 1(b)). We assume that the layer with $S$-wave velocity of $320 \mathrm{~m} / \mathrm{s} \mathrm{con-}$ tinues down to a depth of $25 \mathrm{~m}$. We assume the same ra- 
Table 2. 1-D model at FKO006, FKOS01, and CTI.

\begin{tabular}{ccccc}
\hline No. & $\begin{array}{c}\text { Thickness } \\
\text { at FKO006 }\end{array}$ & $\begin{array}{c}\text { Thickness } \\
\text { at FKOS01 } \\
\text { and CTI } \\
(\mathrm{m})\end{array}$ & $V s$ & Density \\
& $(\mathrm{m})$ & 4 & 110 & 1.78 \\
\hline 1 & 2 & 12 & 130 & 1.76 \\
2 & 6 & 8 & 150 & 1.66 \\
3 & 4 & 6 & 180 & 1.94 \\
4 & 3 & 20 & 320 & 1.87 \\
5 & 10 & - & 600 & 1.90 \\
6 & - & & & \\
\hline
\end{tabular}

tio of each layer thickness in the region shown in Fig. 1(b) to the 1-D model at FKO006. The resultant thickness at FKOS01 and CTI is shown in Table 2. Soil constant of the pre-Tertiary bedrock is taken from Nakamichi and Kawase (2002). $Q$ is assumed $Q=5 f$ ( $f$ is frequency in $\mathrm{Hz}$ ) based on $Q$ inverted from borehole records in Japan (e.g., Satoh et al., 1995). Using the 1-D model in Table 2, we deconvolved the 1-D theoretical amplification assuming vertical incident $S$-waves from FKO006 records to get the preTertiary bedrock wave. Here the pre-Tertiary bedrock wave means the wave calculated under the assumption that the pre-Tertiary bedrock is outcrop, that is, twice of the incident wave at the pre-Tertiary bedrock level.

Figure 5 shows the 1-D site responses of Quaternary sediments s underlain by the bedrock with $V s=600 \mathrm{~m} / \mathrm{s}$ at FKO006, FKOS01, CTI, CT012, and CS081. Figure 6 shows the 1-D site responses of soft soil with $V s$ less than or equal to $180 \mathrm{~m} / \mathrm{s}$ underlain by $V s=320 \mathrm{~m} / \mathrm{s}$ layer at FKO006, FKOS01, and CTI. The predominant periods of site responses of Quaternary sediments and soft soil are similar to each other. Since site responses of Quaternary sediments include those of soft soil, we consider the site responses of Quaternary sediments in this study. To eliminate source and path effects, we show spectral ratios of records at FKOS01 and CTI with respect to those at FKO006 in Fig. 7. The observed spectral ratios are consistent with 1D computed spectral ratios of Quaternary sediments in the period range form the 0.7 to 2 seconds which is the predominant period range of the velocity pulses of the main shock records. This result suggests that the 1-D site responses of the Quaternary sediments can reproduce the difference of the ground motions at three sites in this period range at least in terms of amplitudes without considering nonlinearity of soil. However the peak at 0.6 second at CTI cannot reproduce by 1-D computed spectral ratios. Since the peak of 0.6 second is much less important for building damage than velocity pulses with a period of about 1 to 2 seconds (Kawase and Nagato, 2000), we will try to reproduce it by considering complex amplification effects on higher frequency component in future.

\section{Simulation and Prediction of Strong Motions}

Using the pre-Tertiary bedrock wave as input motions at the bedrock, we simulate velocity ground motions at FKOS01 and CTI by 1-D wave propagation theory. The observed and calculated velocity waveforms are shown in Fig. 4. The PGV of the pre-Tertiary bedrock wave is 52 $\mathrm{cm} / \mathrm{s}$. The simulated velocity pulses with PGV of nearly $80 \mathrm{~cm} / \mathrm{s}$ reasonably reproduce the observed velocity pulses in terms of amplitudes and phases at FKOS01 and CTI, although the simulated PGV is slightly larger than the observed PGV at FKOS01. The predicted PGV at CT012 and CS081 is $81 \mathrm{~cm} / \mathrm{s}$ and that is biggest among all the calculated points. The observed and calculated pseudo velocity response spectra with a damping factor of $5 \%$ are shown in Fig. 8. The simulated response spectra reproduce the observed response spectra in a wide period range from 0.2 to 10 seconds at FKOS01. At CTI the simulated response spectra reproduce the observed response spectra in the period range from 0.7 to 10 seconds.

Figure 9 shows the PGV distribution predicted by considering the 1-D site response of the Quaternary sediments at the target sites and the pre-Tertiary bedrock wave shown in Fig. 4. The predicted PGV is larger in the northeastern side of the Kego fault. The PGV contour is similar to the Quaternary-sediment thickness contour shown in Fig. 1(b). This similarity between them is caused by two conditions. One is that the predominant period of the preTertiary bedrock velocity wave is 1 to 2 seconds. The other is that the predominant period of 1-D site response at the northeastern side of the Kego fault is nearly 1 second that is the longest predominant period among all. The PGV distribution is also consistent with damaged building distribution surveyed by Kawano and Inoue (2005), Kosa et al. (2005), and Kawase et al. (2005). In the most severally damaged area shown in Fig. 2 the predicted PGV is about $80 \mathrm{~cm} / \mathrm{s}$. The similarity between them is reasonable because velocity pulses with a period of 1 to 2 seconds are most influential for the structural damage to ordinary buildings (Kawase and Nagato, 2000). We should note that the PGV in southern area near CS081 may be overestimated by about 7\% due to geometrical spreading of $1 / \mathrm{X}$ because the hypocentral distances $X$ of FKO006 and CS081 are $28 \mathrm{~km}$ and 30 $\mathrm{km}$, respectively.

Matsushima et al. (2005) predicted PGV distribution by using 3D-FDM model of Quaternary sediments and the preTertiary bedrock wave filtered in the period range from 0.3 to 3 seconds. The PGV distribution calculated by the 3-D model is very similar to PGV distribution shown in Fig. 9. This result means that 3-D effects such as basin-edge effect (Kawase, 1996) is negligible to PGV distribution of $\mathrm{N} 20^{\circ} \mathrm{E}$ components. Therefore it can be said that the 1-D site responses of the Quaternary sediments mainly contributed to the difference of PGVs and structural damage observed inside and outside of the damaged area in Fukuoka City. Yamanaka et al. (2005) pointed out that short period ground motions less than $0.4 \mathrm{sec}$ are influenced by 2-D or 3-D basin-edge effects of shallow sediments using aftershock records. However, such short periods are different from influential periods for the structural damage to ordinary buildings. In addition ground motions less than $0.4 \mathrm{sec}$ are small during the main shock as shown in Fig. 8. Therefore the 2-D or 3-D basin-edge effects would not be contributed to the difference of PGVs and structural damage observed inside and outside of the damaged area during the main 


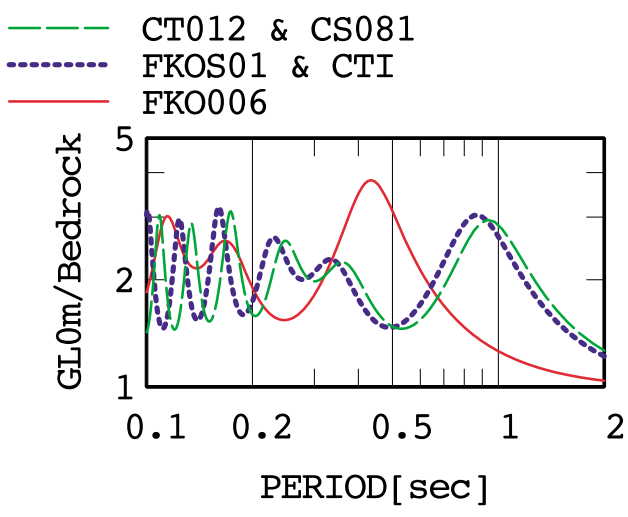

Fig. 5. 1-D site responses of Quaternary sediments underlain by the bedrock with $V s=600 \mathrm{~m} / \mathrm{s}$ at FKO006, FKOS01, CTI, CT012, and CS081.

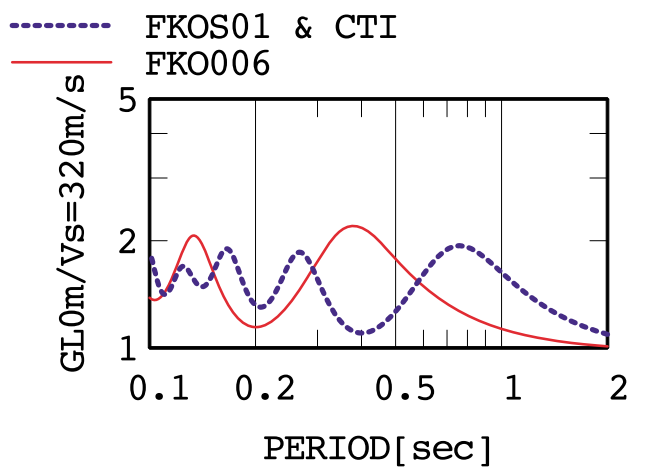

Fig. 6. 1-D site responses of soft soil with $V s$ less than or equal to 180 $\mathrm{m} / \mathrm{s}$ underlain by $V s=320 \mathrm{~m} / \mathrm{s}$ layer at FKO006, FKOS01, and CTI.

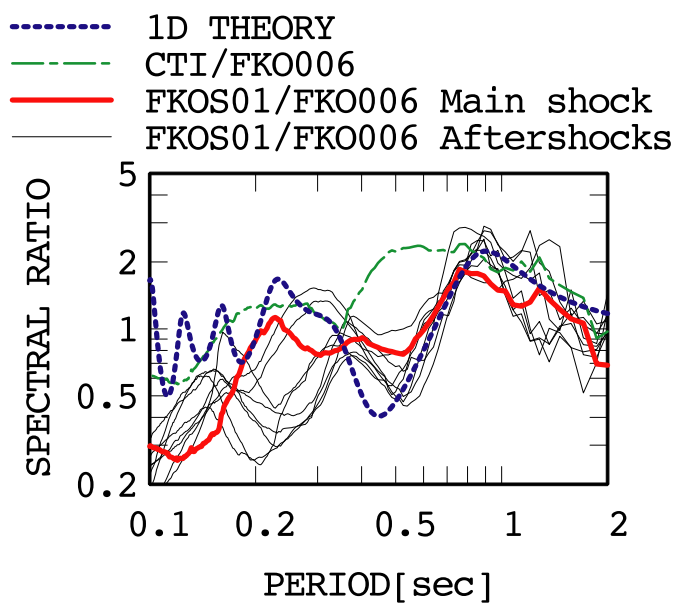

Fig. 7. Observed and calculated spectral ratios of FKOS01 and CTI to FKO006. The calculated spectral ratios denoted by a thick dashed line are the ratios of the 1-D site responses at FKOS01 and CTI to FKO006 shown in Fig. 5.

shock.

\section{Conclusions}

The damaged buildings were distributed in the limited area in the northeastern side of the Kego fault in Fukuoka City (e.g., Kawano and Inoue, 2005; Kosa et al., 2005; Kawase et al., 2005) during the 2005 West Off Fukuoka Prefecture Earthquake. We simulate velocity records at two
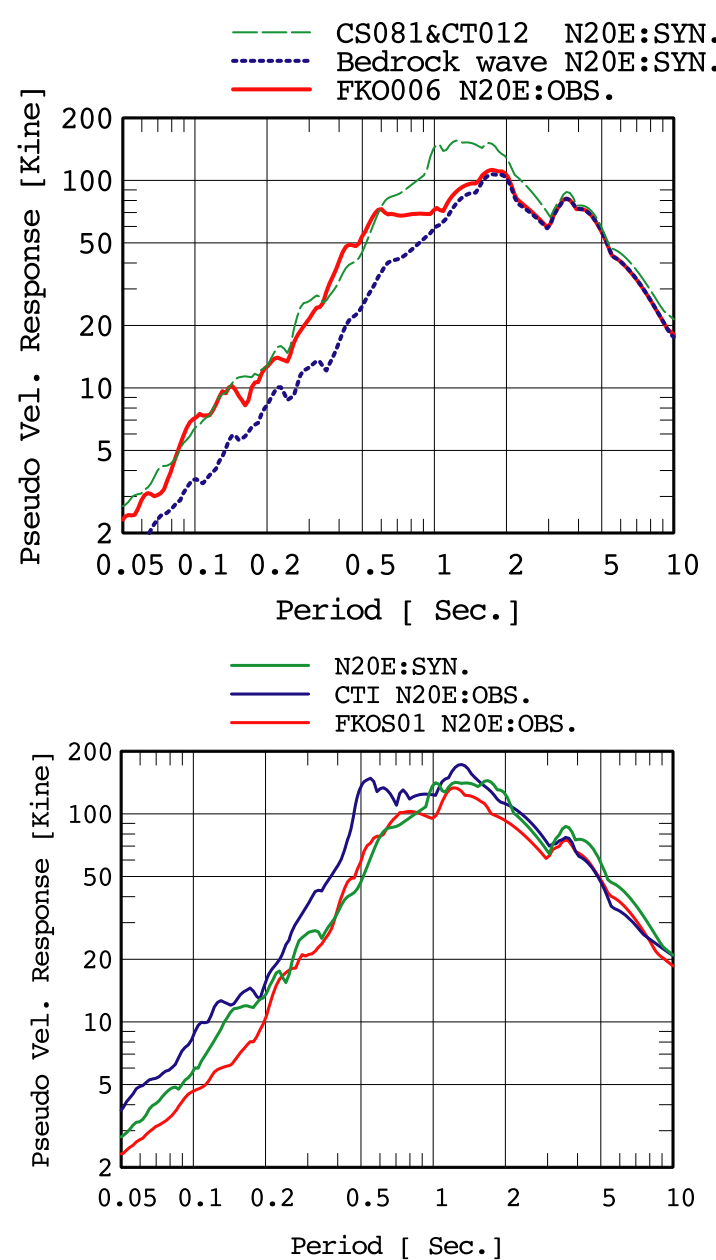

Fig. 8. Observed and calculated pseudo velocity response spectra with a damping factor of $5 \%$.

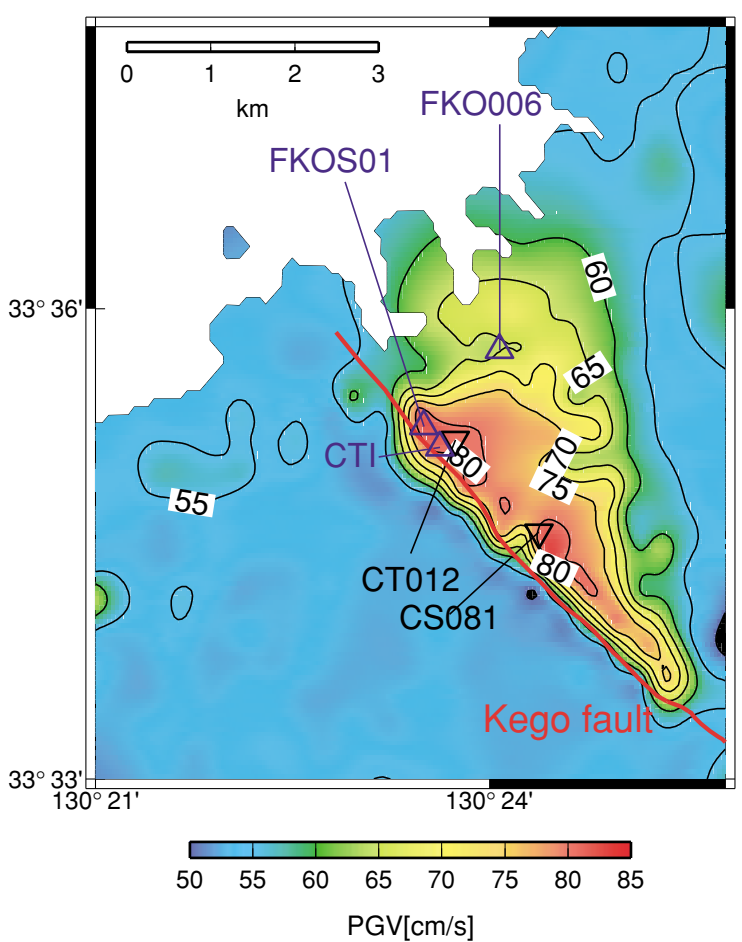

Fig. 9. PGV distribution of $\mathrm{N} 20^{\circ} \mathrm{E}$ components for the main shock predicted by considering the 1-D site responses of the Quaternary sediments. 
stations in the damaged area near the Kego fault in Fukuoka City and predict PGV distribution around the Kego fault by considering 1-D site responses of Quaternary sediments. The pre-Tertiary bedrock wave deconvolved from velocity records observed at a K-NET station (FKO006) outside of the damaged area is used for the simulation and reproduction. The observed velocity waveforms and pseudo velocity response spectra in the period range from 0.7 to 10 seconds of the predominant direction $\left(\mathrm{N} 20^{\circ} \mathrm{E}\right)$ components are reasonably reproduced. Velocity pulses with a period of about 1 to 2 seconds in observed velocity waveforms of the $\mathrm{N} 20^{\circ} \mathrm{E}$ components at two stations are found to be amplified by the 1-D site responses and are hence larger than the velocity pulse observed at FKO006. The predicted PGV distribution agrees well with both the Quaternary-sediment thickness and the building damage distributions. We concluded that the 1-D site responses of the Quaternary sediments mainly contributed to the difference of PGVs inside and outside of the damaged area around the Kego fault in Fukuoka City.

Acknowledgments. We use strong motion records observed by National Research Institute for Earth Science and Disaster Prevention (NIED), Fukuoka prefecture, and CTI Engineering Co., Ltd. We also use the logging results and the F-net fault mechanisms by NIED and hypocenter information by Japan Meteorological Agency (JMA). We would like to thank these organizations to provide data and information. We appreciate Prof. Kawano to kindly provide us a figure on building damage distribution. Prof. R. D. Borcherdt and Dr. Nobuyuki Yamada provided constructive comments that led to a significant improvement of the manuscript. A few figures are plotted with GMT (Wessel and Smith, 1998).

\section{References}

Asano, K. and T. Iwata, Source process and near-source ground motions of the 2005 West Off Fukuoka Prefecture earthquake, Earth Planets Space, 58, this issue, 93-98, 2006.

Editing Group of Fukuoka soil map, Fukuoka soil map, 177 pp., Geological Survey Association of Kyushu (interpreted by authors), 1981 (in Japanese).

Itoh, S. and H. Kawase, Calibration of strong motion prediction method using statistical green's function and its application to hypothesized Fukuoka earthquake, Struct. Constr. Eng., Architectural Institute of Japan, 540, 57-65, 2001 (in Japanese with English abstract).

Japan Meteorological Agency, http://www.hinet.bosai.go.jp/REGS/JMA/ list/, 2005.
Kawase, H., The cause of the damage belt in Kobe: "The basin-edge effect", Constructive interference of the direct S-wave with the basininduced diffracted/Rayleigh waves, Seism. Res. Lett., 67, 25-34, 1996.

Kawase, H. and Damage Investigation Team of the 2005 West off Fukuoka earthquake, Disaster of the 2005 West off Fukuoka earthquake, in Proc. of the Panel Discussion for the disaster committee of Architectural Institute of Japan, AIJ annual meeting, Kinki University, pp. 6, 2005 (in Japanese)

Kawase, H. and K. Nagato, Structural damage impact of strong motions evaluated by the nonlinear analysis of a set of building models, in Proc. Sixth International Conference on Seismic Zonation, Palm Springs, CA, CD-ROM, 00197.pdf, November 13-15, 2000.

Kawano, A. and I. Inoue, Damage of non-wooden buildings, in Report on the damage investigation of the 2005 west off Fukuoka earthquake, Architectural Institute of Japan, 68-110, 2005 (in Japanese).

Kosa, K., S. Hino, T. Matsuda, and K. Torino, Building damage, Part 1, http://www.jsce.or.jp/report/34/tatemono/tatemono_higai1.pdf, 2005 (in Japanese).

Matsushima, S., H. Kawase, and T. Satoh, Site effects in strong motions observed during the 2005 West off Fukuoka earthquake, Part3 Effect of shallow 3-D basin structure, in Summaries of technical papers of annual meeting, Architectural Institute of Japan, B-2, 121-122, 2005 (in Japanese).

Nakamichi, S. and H. Kawase, Broadband strong motion simulation in Fukuoka City based on a three-dimensional basin structure and a hybrid method, J. Struct. Constr. Eng., Architectural Institute of Japan, 560, 83-91, 2002 (in Japanese with English abstract).

Nakata, T. and T. Imaizumi, Digital active fault map of Japan, DVD, University of Tokyo Press, 2002.

National Research Institute for Earth Science and Disaster Prevention, K-NET, http://www.k-net.bosai.go.jp/k-net/ftppub/sitedat/FKO006.dat, 2005a.

National Research Institute for Earth Science and Disaster Prevention, F-net, http://www.fnet.bosai.go.jp/freesia/event/tdmt/20050320015200/ update1/index.html, 2005b.

Satoh, T., H. Kawase, and T. Sato, Evaluation of local site effects and their removal from borehole records observed in the Sendai region, Japan, Bull. Seism. Soc. Am., 85, 1770-1789, 1995.

Suzuki, W. and T. Iwata, Source model of the 2005 west off Fukuoka prefecture earthquake estimated from the empirical Green's function simulation of broadband strong motions, Earth Planets Space, 58, this issue, 99-104, 2006.

Wessel, P. and W. H. F. Smith, New, improved version of Generic Mapping Tools released, EOS Trans. AGU, 79, 579, 1998.

Yamanaka, H., K. Motoki, K. Seo, and H. Kawase, Observation of aftershocks in Tenjin area of Fukuoka city, in Report on the damage investigation of the 2005 west off Fukuoka earthquake, Architectural Institute of Japan, 16-19, 2005 (in Japanese).

T. Satoh (e-mail: toshimi.satoh@shimz.co.jp) and H. Kawase 